\title{
Tourism Destination in Remote Area: Problems and Challenges of Tourism Development in North Halmahera as Remote and Border Areas of Indonesia-Philippines
}

\author{
Yerik Afrianto Singgalen ${ }^{1 *}$, Gatot Sasongko ${ }^{2}$, Pamerdi Giri Wiloso ${ }^{2}$ \\ ${ }^{1}$ Politeknik Perdamaian Halmahera, North Halmahera, North Maluku, Indonesia \\ ${ }^{2}$ Satya Wacana Christian University, Salatiga, Central Java, Indonesia
}

\begin{abstract}
This paper will describe the problems and challenges in North Halmahera tourism development and describe the coordination, resources, disposition of executor and bureaucratic system in the process of tourism policy implementation by local government. This research used a qualitative method and case study approach. The method used in this research is qualitative with case study approach. This research conducted in Kakara Island, Tagalaya Island, Bobale Island, Kumo Island, Luari Beach, Paca Lake, Duma Lake, and Mamuya Hot Spring as the priority in North Halmahera Tourism Development Program by local government. The results of the evaluation indicate that the bureaucratic system, resources (human resources and sources of funding), the disposition of the commissioning and coordination was instrumental in the process of implementation of the policy on tourism. The implications of the implementation of tourism policy hampered are the lack of participation of the community and damage to facilities and access for tourism which threaten the sustainability of tourism. Thus, it can be noted that the challenges in the development of the leading tourist attraction in North Halmahera Regency are the effort to increase community participation through partnerships to achieve sustainable tourism.
\end{abstract}

Keywords: Bureaucracy System, Coordination, Disposition, Resources, Tourism Policy.

\section{INTRODUCTION}

This research will describe the bureaucratic system, resources, disposition, and coordination to identify the source of constraints that occurred through the implementation process. What distinguishes this research from previous studies is that this study describes the problems and challenges of tourism development in remote areas; specifically the border area of Indonesia and the Philippines. This research is important to be implemented considering the Indonesian government's policy of expanding access to the entire archipelago through the policy of marine toll construction and tourism development as a priority of national development. Tourism is one of the important industrial sectors and has great potential and opportunities to be developed. The development of tourism in developing countries, including Indonesia, is expected to help equalize the economic opportunities and hamper villagers to migrate to the city [1]. This study showed the conditions of tourism development in remote areas, problems and challenges faced and the response of local governments to central government policy.

\footnotetext{
*Correspondence address:

Yerik Afrianto Singgalen

Email: singgalen.yerik@gmail.com

Address: Politeknik Perdamaian Halmahera, Wari Ino, Tobelo, North Halmahera, North Maluku, 97762.
}

Previous studies showed that government in the development of regional tourism has the role as operator, regulator, designer, coordinator, and educator [2,3]. This shows that the development and sustainability of tourism are also determined by the implementation of tourism policies by the government. Furthermore, Truong [4] shows that the government in tourism development has a very important role as a policymaker and as a tourism policy executive, although the perspective used is a pro-poor perspective.

Government intervention through tourism policies in favor of local communities is not always considered as good. As indicated by Whitford and Ruhanen [5] that government intervention through tourism policies to mobilize market growth and product development should not use a one-for-all measure; it only demonstrates sustainable retrograde rhetoric without steps concrete. Thus, policies need to utilize diversity, collaborative, coordinated and integrated, in the capacity building of communities to achieve sustainable tourism. Thus, it can be seen that the implications of the implementation of tourism policies affect the sustainability of tourism. 
The implications of tourism policy on the sustainability of the tourism sector can be seen from the monitoring and evaluation of policy directions and strategies of tourism development. Scholar suggests that a critical approach in evaluation emphasizes the context of tourism development programs, the climate of intervention, arrangement, evaluation context and decision-making context in identifying market dimensions, stakeholders and programs that have been formulated [6]. It is necessary to know which parties are most benefited from the implementation of policies, either local communities, the environment or stakeholders. Tourism policy should be integrated with the interests of local communities and stakeholders in tourism, this will encourage inter-sectoral partnerships or collaborations so as to achieve good governance and sustainable tourism [7].

The evaluation of tourism policy is a strategy to achieve sustainable tourism, it can be seen from various development contexts. Just as the previous study suggested that an evaluation of tourism policy is needed to reduce economic growth as a result of tourism development that affects aspects of sustainability [8]. On the other hand, the evaluation of tourism policies can sustain business development, when climate change becomes a serious problem affecting tourism sustainability [9]. In addition, the importance of evaluating tourism policies and their impacts on social and cultural aspects [10]. Research on the evaluation of tourism policy has been done before $[11,12]$. However, the context of policy implementation always yields different results.

Pallewa uses George Edward III theory of communication, resources, disposition and bureaucratic structure affecting tourism policy implementation in North Toraja District [13]. Communication is needed to establish personal interaction among tourism actors in expressing the desire and plan of tourism program implementation, as well as to reach prospects and opportunities in the field of tourism-based economy. In addition, adequate human resources in terms of quality and quantity can support the implementation of tourism policy, thus contributing positively to the realization of tasks and responsibilities in every tourism development program.

As for the process of disposition in the implementation of policies as outlined in the form of work programs, the delivery of strategic ideas becomes a symbol of the ongoing disposition from and toward the implementation followed by a strong understanding. Regarding the disposition of the implementer, the organizational structure regulates the flow of work so that each has a duty and no longer interfere with other tasks. Based on this, the researcher will describe the performance evaluation in tourism policy implementation process in North Halmahera, Indonesia.

The public can participate in the decisionmaking process at the stage of planning the development of a tourist attraction especially in an effort to formulate a program of development of tourism which is able to alleviate poverty as demonstrated $[14,15]$. Through community involvement in the decision-making process, the community can determine the direction of the development. Even though, Li [16] shows that local communities obtain economic benefits without engaging in the planning process. In addition, Simpson [17] shows that community involvement in the planning stages especially on the decision-making process does not guarantee the distribution of the profits evenly, but can cause a number of problems or conflict interest in the program development.

The government as a driver of tourism development seeks to increase public participation in the tourism sector so that the policies formulated is a joint decision. Thus the sense of ownership of any tourism development program becomes a motivation in overcoming every impact of tourism activities. The problems related to tourism policy are efforts to control the corporation of travel business by foreign investors and migrant entrepreneurs [18]. Thus, to achieve an equitable distribution of benefits from the tourism sector between local communities and other entrepreneurs, tourism policy is required.

In the process of implementation of the policy on tourism, socio-cultural conditions of political, economic, and also has a very important role. The availability of resources, communication and coordination, as well as socio-cultural conditions, politics and economics plays an important role in the implementation of their development programs [19]. In addition, evaluation is needed to control the impact of tourism activities. Indraswara [20] have shown that in evaluating the government performance, the efforts on the utilization potential of natural resources are to be projected with emphasis on the welfare of life. The existence of business accommodation has exceeded the environment capacity thus lowering resources support and influence the ecosystem. It means that, the challenge to achieve sustainable 
tourism is not only seen from the economic aspect but also social and environment sustainability. The effort to achieve the goal of sustainable tourism is to obtain economic, social and environmental benefits by tourism policy as demonstrated in previous studies [21-25]. Thus it can be seen that the program to optimize the economy, social and environment can be a strategy to achieve sustainable tourism.

\section{MATERIALS AND METHOD}

The method used in this research is qualitative with case study approach. This research conducted in Kakara Island, Tagalaya Island, Bobale Island, Kumo Island, Luari Beach, Paca Lake, Duma Lake, and Mamuya Hot Spring as the priority in North Halmahera Tourism Development Program by local government. Case study approach is used to describe the problems and challenges in North Halmahera tourism development process. The stages of this research are divided into Preparatory Phase, Research Location Setting Phase, Data Collection Process Stage and Data Validation Process Stage.

\section{Preparation Stage}

At the preparatory stage, the researchers conducted scientific searches related to the theme of tourism area in remote areas including rural areas even in the outer regions or borders of Indonesia. Based on the theme, researchers set up a research framework to describe the dynamics of tourism development in remote areas or Indonesia's outermost regions to identify problems and challenges facing local governments, in particular, the Tourism Office. Based on that, the researcher chose North Halmahera Regency located in the eastern part of Indonesia and included border area between Indonesia and the Philippines.

\section{Study Area}

At the stage of determining the location of this study, researchers consider the social and cultural context of local communities including the language used to facilitate the process of data retrieval. The results of the document of Regional North Halmahera Regency in 2011 showed that North Halmahera Regency has 56 tourism potentials spread in each sub-district. Meanwhile, the category of tourism potential includes natural attractions, maritime and beaches, history, and culture. Considering the limitations of access and coverage to all areas of regional tourism potential, the researcher decided to focus on the preeminent tourist attraction that has been established by the local government of Kakara Island, Tagalaya Island, Kumo Island, Bobale Island, Luari Beach, Talaga Duma, Talaga Paca, and Mamuya Hot Spring. Access to research location can be reached by researchers easily because of the availability of transportation modes and other public facilities that support the data retrieval process

\section{Data Collection}

At the data-taking stage, researchers need a process of adjustment or adaptation with local communities in the eight leading tourist attraction. This process is done to build good relationships and communication so as not to create a suspicious impression for the local community.

In the early stages of adaptation, researchers position themselves as tourists who become customers at a restaurant or gathering place residents in the environment of a tourist attraction. Researchers began sharing stories and experiences while eating and drinking to create a familiar atmosphere with local communities. The process is done repeatedly so that researchers have an intense time to visit the location of the attraction. In the adaptation process, researchers selectively view potential individuals as key informants. Key informants are selected taking into account individual experience and knowledge related to the tourism development process. Researchers also consider the educational background, occupation and residence of informants.

After finding the key informants in each of the leading tourist attractions, researchers convey the intent and the real purpose of making a scientific article. This was reassured by an official research letter from North Halmahera District Government and supported by an official research letter from the university. Communication relationships that have been built before, into consideration for the key informants, thus they are willing to provide information needed in depth. Thus, the researchers set a time to meet specifically to discuss the various problems and challenges that occur in the dynamics of development of attractions in Kakara Island, Tagalaya Island, Kumo Island, Bobale Island, Luari Beach, Talaga Duma, Talaga Paca, and Mamuya Hot Spring.

After the in-depth interview process was completed, the researcher along with the key informants visited the location of the tourist object to reassess or match the information that has been submitted with the actual condition (the 
physical condition of the environment). Some informants described the conflict between the landowner and the village government, to the misconception that the internal government areas and their impact on the sustainability of tourist attractions. The results of in-depth interviews indicate a problem that makes informants reluctant to publish their identity in the writing of scientific articles. Considering this, the researchers agreed not to publicize the identity of informants to informants who did not want to be published. This research only publishes the identity of informants who are willing. Thus, the data retrieval process can run well. Thus briefly it can be said that Participants of this research are local government officers (AU, YA, SP), Local Community (NN, JF, HH, PS, RB, TD, EK, MP), Head of North Halmahera Tourism Department in 2015, (TS) and Head of North Halmahera Tourism Department in 2016 (JBM).

\section{Data Validation}

At the stage of data validation, the researcher uses triangulation technique by reconciling the information received with the actual conditions and the results of the study document such as Regional Tourism Master Plan in 2011, the Strategic Plan of the Tourism Department, and the Medium Term Plan of the Tourism Agency. In order to fill the gap in the analysis, we also use the document such as Tourism Destination Master Plan in 2008 to sharpen the analysis in this study and find the constraints or problem in the implementation process. In addition, researchers also utilize information technology, especially social media and communications to trace the information and ensure the information received suitable with the actual conditions. After the data validation process, the researcher narrates the research result about the performance evaluation in the tourism policy implementation process.

\section{RESULT AND DISCUSSION \\ Governmental Tourism Policy}

Local Government in North Halmahera District has four main aspects in tourism policy development, such as destination management policy, tourism industry policy, tourism marketing policy, and human resources development policy. It is included in the regulations in North Halmahera Regency (Table 1). Policy formulated should be integrated with the needs of local as demonstrated by several studies [26-30]. Local Government plays an important role in the policy implementation process to achieve sustainable tourism development as demonstrated [31,32].
Furthermore, community-based approach is used to increase the level of participation or local community involvement in the development process. In fact, there are obstacles and problems arise in the implementation process.

Table 1. Regional Regulation in North Halmahera Regency related to the Tourism Policy

\begin{tabular}{|c|c|}
\hline $\begin{array}{l}\text { Regional } \\
\text { Regulation }\end{array}$ & Regulated Matters \\
\hline No. 9 on 2013 & $\begin{array}{l}\text { Master Plan for Tourism Development of } \\
\text { North Halmahera Regency }\end{array}$ \\
\hline No. 8 on 2016 & $\begin{array}{l}\text { The Establishment and Composition of } \\
\text { North Halmahera District }\end{array}$ \\
\hline No. 37 on 2016 & $\begin{array}{l}\text { Organizational Structure of Main Duty } \\
\text { and Function of Tourism Office of } \\
\text { Halmahera Regency. }\end{array}$ \\
\hline
\end{tabular}

The local government reform bureaucratic system in Tourism Department by displace the Cultural Sub-Department and establish CreativeEconomic Sub-Department as a strategy to enhance the development of tourism industries in North Halmahera. According to North Halmahera Master Plan for Regional Tourism Development 2011, the existence of cultural department influences the theme of development even the programs, which are dominated by cultural preservation. In 2016, the creative-economic department replaced the cultural department based on North Halmahera Master Plan for Regional Tourism Development 2016.

Local Government provides funding system and utilize the human resources in the Tourism Department to optimize the tourism policy implementation process. In addition, tourism development in North Halmahera is still immature and the human resources as an expert in tourism are limited. However, the funding system supports all the programs to enhance sustainable tourism goals.

Tourism Department utilizes funding support to develop human resources in tourism as an expert. Unfortunately, in the early stages of tourism development process, dispositions performance are not qualified as professionals and causes the lack of tourism development programs in 2014 and 2015. In addition, low level of coordination between local government and local community causing problems in tourism development process such as land disputes. Thus, community involvement becomes essential in tourism development.

Albrecht [33] showed that partnerships as the solution to solve problems and increase the level of participation. On the other hand, Jovicic [34] showed that the efforts to achieve sustainable 
tourism is inseparable from the support of the community, good governance reflected adequate tourism infrastructure. While Sakata and Prideaux [35] showed that community involvement in the development of tourism in rural or remote area has its own way in developing tourism, including governance system.

\section{Tourism Condition in North Halmahera}

Problems arising from the lack of coordination with local communities are land disputes and damaged facilities, such as the case of Kakara Island in North Halmahera in Figure 1. Figure 1 shows that lack of coordination between local government and landowner causes problems such as land disputes and causes resistance of the local community to maintain tourism facility.

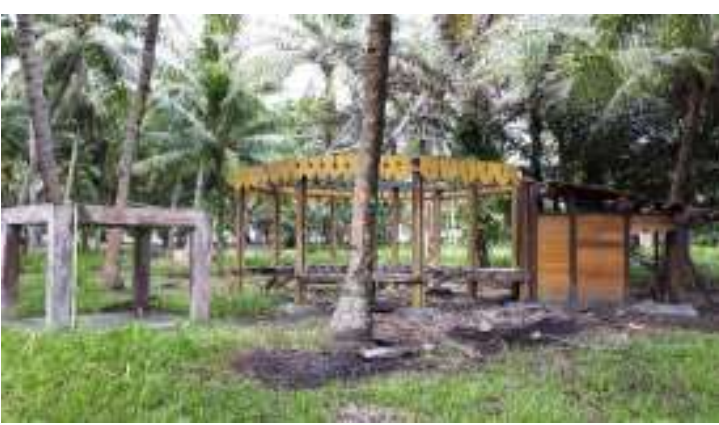

Figure 1. Tourism Facility in Kakara Island, North Halmahera, Indonesia on 2017

(Source: personal documentation)

The same case happend in Tagalaya Island, based on the results of the interview with SP as the local community in Tagalaya Island shows that the problem of land disputes hamper the development of tourism, as follows:

"The problem in tourism development in Tagalaya was disrupted by land disputes. Before, we villagers worked together to clean up the village environment including making roads along the coast to the bridge. When there was a visit from the marine and fisheries department, we were given assistance for tourism, they provide support in the form of homestay building as a supporter of tourism. At that time, we agreed to build around the bridge, the construction project went well until it was done. We also have the community to participate in the foundation construction in the north, which in the north are all the contribution of society, we want tourism to grow. After the building is finished, the domestic and foreign tourists began to visit, we had time to manage the entrance fee of 1000 IDR person but we usually calculate based on the boat used (Katinting) can reach 5000 IDR depending on the type of boat, if the boat larger (Pamboat) the price is also different. Income derived from the tourism sector, quite good for village income. However, not long after that, we received information about a lawsuit from the landowner to the village, the lawsuit was processed by law to the court. Initially, the village won the battle, but when the landlord appealed, we lost. There was a misunderstanding between the Marine Office and the Tourism Office because the building is a Marine Office's support not from the Tourism Office, but I do not really understand how it goes. The information I got from the government has lobbied with the landlord but apparently, the landlord refuses to accept the offer of land acquisition and chooses to sell the land to another party at a cheaper price than the government offers. After winning the case, the landowner immediately remodels the homestay building that has been built. Our constraint is that there are no stalls selling food so that when tourists come here, they bring their own food. If they do not bring their own food then their visit will not stay long".

The local government program to provide restaurants for the local community in Tagalaya beach, Kumo beach, Kakara Island, Luari Beach, Duma Lake, Paca Lake, Mamuya hot Spring, and Bobale Beach has not been implemented. Nevertheless, local communities volunteer to participate as entrepreneurs and build their own restaurants. It shows that local government was not able to provide tourism facilities. Based on indepth interviews with Ms. N, it can be seen that tourism support facilities in Mamuya Hot Spring still limited, as follows:

"I am N's mother, I have been nine years old managing this tourist attraction. Since Mr. Sb lead the tourism official in North Halmahera District, he often comes and visits this place. Furthermore, when Mrs. Mh lead the tourism officiall, she rarely comes here. This Land previously owned by local people and they sold it to the government. But the problems still occur because the lack of tourism infrastructure support, for example, there is no electricity here and trash bin are limited. Sometimes I have to argue about the tourist behavior, they throw away trash or plastic bag into the hot spring. This habitual action becomes an obstacle because I have to make it clean every day without payment. The local government still find the solution about funding support to utilize the Mamuya Hot Spring destination management, but still on the process. We have to wait. All that we have to do is selling the parking tickets, and 
cleaning the area. In the future, I hope the local community are able to participate and fill the economic benefit of tourism development. Especially for a woman in the village, we hope there will be a place for them to sell their product and increase their income."

Based on the results of interviews with N's mother, it can be seen that there are limitations of local people to enjoy the results from the existence of the tourism sector. Without involving the local community in the develop-ment or maintenance of an infrastructure supporting tourism, then the potential damage to the infrastructure is higher. It can be seen from the bridge development program of Tagalaya, Talaga Paca, and Kakara that has been implemented but some of them are not well maintained, thus it is damaged.

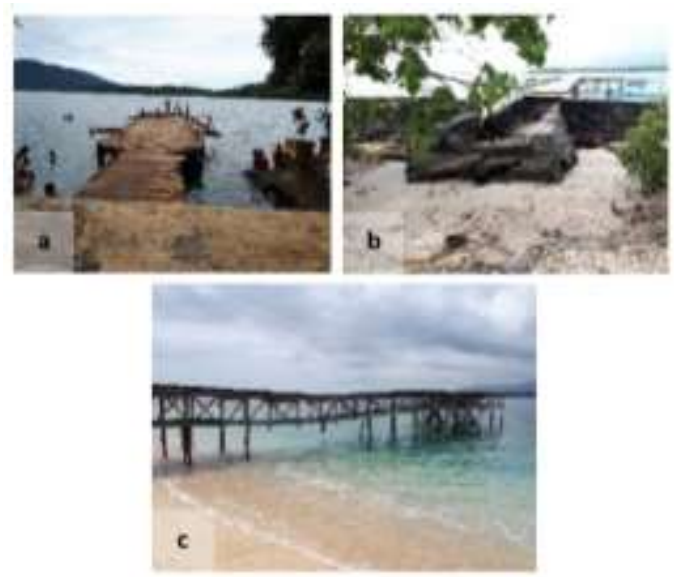

Figure 2. The Physical Condition of the Bridge, in a) Tagalaya Beach Attractions, b) Kakara Island, and c) Paca Lake

(Source: Personal Documentation)

To keep the destination remain safe and clean, the involvement of local communities in the development of tourism is becoming very important. By setting up the business area for local community, the citizen was given the opportunity to gain income from tourism development. Due to the case of Tagalaya Beach and Kakara island, constrained derived from completion of land acquisition. On the other hand, Paca Lake, Duma Lake, Mamuya Hot Spring, and Bobale Island were not provided area for locla communities. Unlike the case of Luari and Kumo beach where local government provide an area for local communities. Compare to another destination such as Bobale Island, local community are not involved in tourism development. However, there were community products such as shells and pearls craft. By providing opportunities for local communities in the destination area, the communities are able to involve as merchants and able to maintain the security and preservation of an area. Further, the lack of support and low level of participation can be threats to the sustainability of tourism in North Halmahera (Fig. 3).

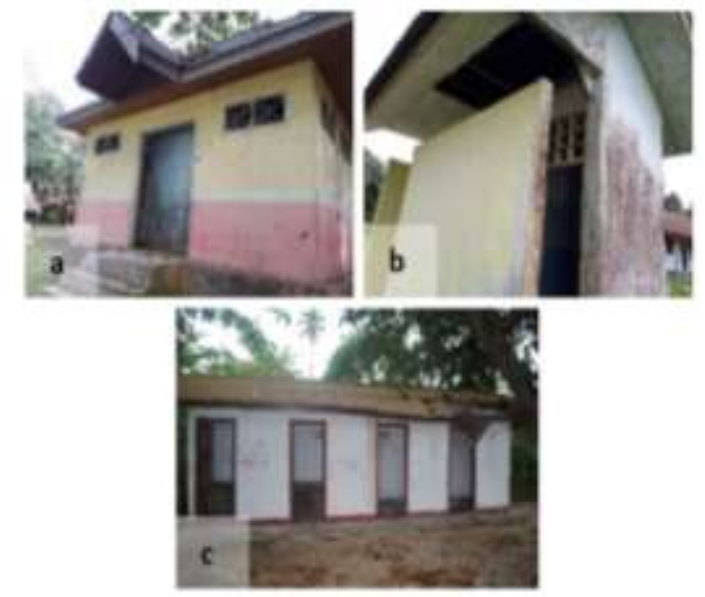

Figure 3. The Condition of Tourism Infrastructure Support, in a) Bobale Island, b) Luari Beach, and c) Paca Lake

(Source: Personal Documentation)

In an effort to maintain the comfort of tourists in the location of tourist attractions, tourist security and vehicle security need to be improved. Security conditions in tourism destination of North Halmahera Regency show that the security settings in each tourist attraction are different. As well as security arrangements at Kumo Beach, Bobale Beach, Mamuya Hot Spring, Duma Lake, and Paca Lake still rely on the awareness of tourists and local people to maintain security together. On the other hand, the security arrangements in Tanjung Kakara and Tagalaya Beach attractions are not sustainable due to constraints of land disputes. Unlike the case of security arrangements in Luari Beach attractions which involve local people as special officers to safeguard the security of tourist vehicles, involving authorities to maintain security at tourist sites during peak/high season, and involving National Agency for Search and Rescue (Basarnas) to keep tourists' security who swim in Luari beach (Fig. 4).

In addition to security arrangements, hygiene arrangements are also not evenly distributed throughout the tourism destination of North Halmahera Regency. Even though trash facilities are available, not all tourist attractions have 
hygiene settings. The results of observation indicate that the arrangement of cleanliness at Tanjung Kakara Island tourist attraction, Bobale Beach, Tagalaya Beach, Paca Lake, and Duma Lake are not sustainable. On the other hand, the attractions of Kumo Beach, Mamuya Hot Spring and Luari Beach already have environmental hygiene arrangements at tourist sites. In the context of Duma Lake tourist attraction, waste bins facilities are available but the arrangements on environmental cleanliness are not sustainable (Fig. 5).

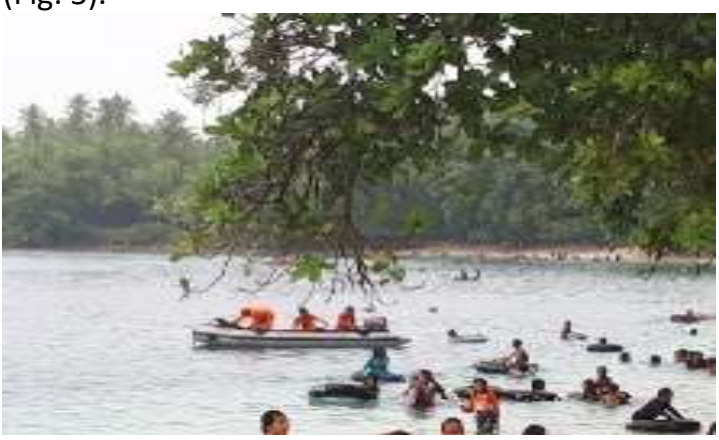

Figure 4. Security Setting in Luari Beach (Source: Personal Documentation)

The price list for entrance to the destination is very varied, it can be seen from the difference of admission price to Luari Beach and Mamuya Hot Spring. Arrangements for admission to Mamuya Hot Spring attractions are not calculated based on the number of tourists but are based on vehicles used by tourists. Special two- and three-wheeled vehicles, charged 5000 IDR and for a four-wheeled vehicle charged 20.000 IDR. Unlike the case with Luari Beach attractions that set the price of admission based on the number of tourists and the type of vehicle used. Entrance fee per individual charged 2000 IDR, for a two wheeled passenger ticket charged 3000 IDR; entrance ticket of three-wheeled vehicles charged 5000 IDR, a four-wheeled vehicle ticket is charged 20.000 IDR and the entrance ticket of a vehicle with the type of truck or bus, is charged 30,000 IDR. Meanwhile, ticket sales post has a distance of approximately 500 meters up to 1000 meters with the location of the attraction.

The determination of entry fee based on the type of vehicle of tourists. It is also adjusted to the condition or area of the parking lot at the location of the tourist attraction. On the other hand, not all the tourism destinations has a parking lot arrangement, as most are archipelago areas. Parking arrangements are only applied at Paca Lake attractions, Luari Beach and Mamuya Hot Spring.
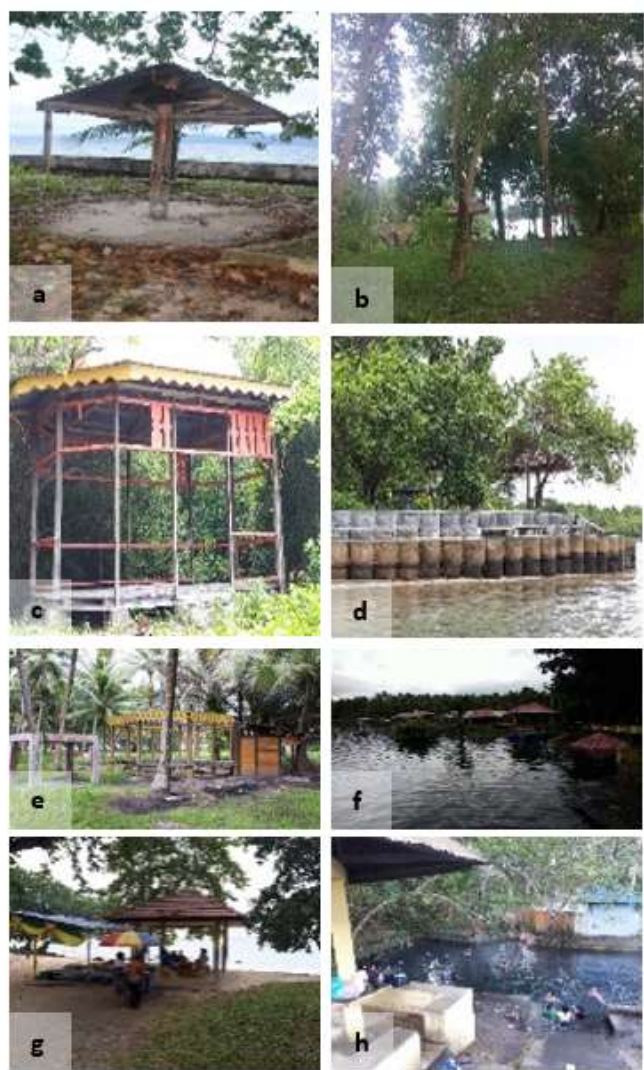

Figure 5. Condition of Tourism infrastructure Support, in a) Bobale Beach, b) Duma Lake, c) Tagalaya Beach, d) Kumo Island, e) Kakara Island, f) Paca Lake, g) Luari Beach, and h) Mamuya Hot Spring (Source: Personal Documentation)

\section{Management of Tourist Destinations}

In the mapping problem of tourism, we identified some very essential matters in organizing the task function Tourism Regional Work Unit. In includes the necessity of increasing the number of foreign tourists, inadequate construction and develop-ment tourist destinations (especially in the archipelago), the need for increasing cultural festival, inadequate art and cultural facilities and infrastructure. It is not only for its optimal preservation of historic and cultural heritage objects, it is as well as the need for an inventory of objects on historical and cultural heritage.

The need for an increase in the number of tourists is very important in order to increase the income of the region. Cross-sector turnover ranging from transportation and accommodation through visits of tourists, become the challenges for Tourism Office of North Halmahera Regency. Therefore, partnerships between stakeholders in the field of tourism is needed. It is also essential to integrate all stakeholders in the development of North Halmahera tourism. In addition, Tourism 
Office also need the attempt to fix the supporting infrastructure tourism while also providing guidance for the people to realise Sapta Pesona around tourist attractions.

Since 2005-2016, Local Government of North Halmahera Regency or Halmahera Tourism Office does not yet have a superior tourist destinations. According to the interview result with TS (20132015) and JBM (2016-2018) as the leader of Tourism Official shows that non of the tourism destination become superior because of land disputes, lack of coordination with land-owning communities, and low level of community participation.

"The determination of regional tourism development priorities is still done unilaterally. We seek to work with landowners to build tourism support facilities so that landowners gain economic benefit from tourist. Meanwhile, the government will get benefit from profit sharing with landowners. But problems begin to appear when landowners refuse to continue cooperation with the government so that tourism development planning that has been formulated in Regional Tourism Master Plan cannot be implemented. This happens in some tourist attraction such as Tagalaya Island and Kakara Island. In addition, community participation is very low."

During this time, management of tourist destinations in its development is still partial and in collaboration with the owner of the land. Thus, the management of tourist attractions still belongs to a private property. This affects the revenue sharing area. In an effort to resolve the issue, the need for the acquisition of land for the construction of a tourism destination that is fully managed by the local government through the Tourism Department of North Halmahera Regency.

The importance to increase cultural festivals for tourism development is the globalization challenges for Tourism Office of North Halmahera Regency. On the other hand, to facilitate infrastructure in the field of Arts and culture, Tourism Office of North Halmahera Regency attempt to complement the needs of art and cultural facilities and infrastructure.

In addition, in the context of North Halmahera, there are areas that have a history and cultural heritage objects, but not everything is well documented. So far, there are 54 kinds of historical relics are well documented. It can be seen from the results of the observation team of Archaeology Hassanudin University in 2014. The observation shows the region of Gotalamo, Kao, and Malifut as the location of the archaeological site. Overall, there is 22 location distribution site that consists of 60 kinds of archaeological remains (a pre-colonial period until colonial Japan).

\section{Direction of Tourism Development}

In a preliminary report on Tourism Development from Master Plan of North Halmahera Regency year 2008 recorded that the vision of tourism development is to increase people's income and the area, improving the quality of human resources, impartial on middle to bottom, entrepreneur partnership between regions, the public and private sector employers, encouraging the increase of the role and contribution of the secondary economy, increase independence and justice, guarantees the harmony of relations among humans, the environment, and the Almighty. This indicates that the planning and development of tourism policy of North Halmahera Regency emphasized three main aspects that are economically viable, socially acceptable, and environmentally sustainable. Thus the knowable existence of North Halmahera tourism manifesting efforts sustainable ecotourism, marine-based history, and culture towards the welfare of the people.

The effort to achieve the goal of tourism development as described in North Halmahera tourism development vision is to obtain economic, social and environmental benefits. According to the interview result with JBM as the leader of Tourism Office 2016, shows that an effort to achieve economic benefits are made by increasing the capacity of human resources in tourism.

"We set strategies to improve the economy by increasing the capacity or human resources development in terms of a creative economy. It is also supported by tourism policy by forming regional development of creative industries department in tourism official to improve the tourism entrepreneurial skill and spirit. Thus, people who live around the tourist attraction area will gain economic benefits. In addition, expertise in entrepreneurship is able to improve survival skills and the ability to improve the welfare of living standards. Economic sustainability will affect social and environmental condition. Therefore, we will start by forming partnerships among tourism stakeholders."

Things that relate to the efforts to establish a partnership between the regions, as well as 
cooperation among stakeholders through the tourism sector, has been discussed. It is related to the patterns of the partnership between local government, the private, and the public, which showed an attempt to find solutions to the benefit of each party's interest by looking at the needs, vision, and goal to make a deal with. In the context of community-based tourism, partnerships between Governments and the private are maintained, as well as the local communities.

In the final report of the Regional Tourism Development Master Plan of North Halmahera Regency year 2011, tourism development planning in Halmahera Regency is divided into four parts, namely the tourism industry, tourism destinations, tourism marketing, and institutional tourism. Based on the foregoing, the implementation of community-based tourism approach that examined in this study focus on the development of tourism destinations and tourism, especially at institutional empowerment and the development of human resources. This indicates that the integration between concepts, planning and policy became the basis of local government before building a partnership with the various stakeholders in achieving the objectives of developing regional tourism.

The development direction of institutional and human resources in the final report of the Regional Tourism Development Master Plan of North Halmahera Regency on 2011 focus on improving The human resources ability for the staff and the leadership of the Tourism Official, trade in partnership with other investors, tour act by the local community, improve the administrators' awareness of the tour, a tour guide and crafting entrepreneurship. The direction of development in capacity building of human resources dominated the course of appeal or an apprenticeship in other areas. In addition, counselling and coaching is focused on conscious group tours and tourist services or manager for the object of tourism attraction.

Even so, the direction of development is also considering an effort to develop a management model that involves the local communities from the planning process up to the monitoring and evaluation of development programs of interest Policies and strategies to improve the quality of human resources as well as the role of the community in the development of tourism in North Halmahera Regency conducted as follows: socialization of tourism to improve the understanding of local communities concerning tourism and supporting aspects; develop the creative economy enterprises or partners for entrepreneurs of tourism services; the improvement of the quality and professionalism of tourism services as well as the trade policy makers in order to understand and manage destinations well.

The theme of Tourism developement in North Halmahera is marine tourism and ecotourism. The consequences of establishing coastal tourism development themes are changes in coastal environmental conditions [36]. Thus, it is necessary to conducted preventive steps to maintain environmental sustainability in coastal areas. Coastal tourism development products are caught up in three S (Sun, Sea and Sand) that are particularly susceptible to climate change, tidal and other impacts such as erosion and floods that indicate coastal environmental degradation [37]. To optimize the development of tourism, we need to be built adequate access [38]. Komarsa explained that in order to achieve sustainability, a priority scale of development is needed [39]. In this context, the local government can identify economic develop-ments, tourism potentials, the efficiency of management.

Furthermore, Iorio and Corsale [40] shows that partnerships as a strategy to address the problems posed by changing environmental conditions. This requires collaboration in formulating strategies to maintain the sustainability of the tourism sector $[21,41,42]$. To resolve the issues, local governments should establish partnership with the land owner.

Other challenge in the process of tourism development is level of participation in the development process. Conflicts that occur due to differences in global priority interests with the needs of local people in the tourism sector also affect the sustainability of tourism supporting facilities and infrastructure [43]. Thus, it is necessary to conduct cooperation and efforts to adjust the interests of local government with the needs of local communities [44-50]. Thus it can be seen that partnership becomes a strategy to achieve sustainable tourism.

\section{CONCLUSION}

The results of this research indicate that the bureaucratic system, resources (human resources and sources of funding), the disposition of the commissioning, and the coordination was instrumental in the process of implementation of the policy on tourism. The hampered implications on the implementation of tourism policy are the lack of participation of the community and 
damage to facilities and access for tourism which threaten the sustainability of tourism. Thus, it can be noted that the challenges in the development of the leading tourist attraction in North Halmahera Regency are an effort to increase community participation through partnerships to achieve sustainable tourism.

Problems in the development of North Halmahera tourism objects indicate the existence of a governance system that has not been the object of interest. As a growing tourist area, the role of local governments, in this case, Tourism Office of North Halmahera Regency, is very important in maintaining the sustainability of tourism facilities and access that has been built, and also empower local communities in the management and maintenance of facilities for tourism. The performance evaluation in tourism policy implementation processes in North Halmahera District shows that lack of coordination between local community influence the level of participation, even cause several problems such as land disputes.

\section{REFERENCES}

[1] Parmawati, R., Y. Saktiawan, F. A. A. Wibowo and A. S. Kurnianto. 2018. Analysis of village tourism development in Sawahan, Trenggalek Regency, Indonesia: a sustainable livelihood approach. E-Journal of Tourism 5(1), 46-53.

[2] Mardiany, M. 2017. Tourism in Samarinda City, East Kalimantan: recent status and future directions. Journal of Indonesian Tourism and Development Studies 5(1), 4148.

[3] Sekarsari, R., and A. Wijaya. 2014. Spatial planning in perspective of good governance (a study on analysis of spatial planning in Batu City as a tourism city). Journal of Indonesian Tourism and Development Studies 2(1), 10-18.

[4] Truong, V. D. 2013. Tourism policy development in Vietnam: a pro-poor perspective. Journal of Policy Research in Tourism, Leisure and Events 5(1), 28-45.

[5] Whitford, M. M. and L. M. Ruhanen. 2010. Australian indigenous tourism policy: practical and sustainable policies? Journal of Sustainable Tourism 18(4), 475-496.

[6] Taplin, J., D. Dredge and P. Scherrer. 2014. Monitoring and evaluating volunteer tourism: a review and analytical framework. Journal of Sustainable Tourism 22(6), 874897.
[7] Dredge, D. and M. Whitford. 2011. Event tourism governance and the public sphere. Journal of Sustainable Tourism 19(4-5), 479499.

[8] O'Sullivan, D., D. Pickernell and J. Senyard. 2009. Public sector evaluation of festivals and special events. Journal of Policy Research in Tourism, Leisure and Events 1(1), 19-36.

[9] Coles, T., A. K. Zschiegner and C. Dinan. 2013. Climate change mitigation policy and the tourism sector: perspectives from the South West of England. Journal of Policy Research in Tourism, Leisure and Events 5(1), 1-27.

[10] Robsertson, M., P. Rogers and A. Leask. 2009. Progressing socio-cultural impact evaluation for festivals. Journal of Policy Research in Tourism, Leisure and Events 1(2), 156-169.

[11] Fandaru, R. R. A. 2016. A new design of Raskin Program (an analysis of the RASDA implementation in Kulonprogo Regency). Jurnal Kebijakan dan Administrasi Publik 20(1), 69-83.

[12] Rutherford, J., H. Kobryn and D. Newsome. 2015. A case study in the evaluation of geotourism potential through geographic information systems: application in a geology-rich island tourism hotspot. Current Issues in Tourism 18(3), 267-285.

[13] Pallewa, A. 2016. Implementasi kebijakan pengembangan pariwisata pada Dinas Kebudayaan dan Pariwisata Kabupaten Toraja Utara. Jurnal Katalogis 4(7), 181-192.

[14] Chok, S. and J. Macbeth. 2007. Tourism as a tool for poverty alleviation: a critical analysis of pro-poor tourism and implications for sustainability. Current Issues in Tourism 10(2), 144-164.

[15] Zhao, W. and J. R. Ritchie. 2007. Tourism and poverty alleviation: an integrative research framework. Current Issues in Tourism 10(2), 119-143.

[16] Li, W. J. 2006. Community decision making participation in development. Annuals of Tourism Research 33(1), 132-143.

[17] Simpson, M. C. 2008. Community benefit tourism initiatives- a conceptual oxymoron? Tourism Management 29(1), 1-18.

[18] Wu, Y., H. Xu, and A. Eaglen. 2011. Tourismdependent development: the case of Lijiang, Yunnan Province, China. Journal of Policy Research in Tourism, Leisure and Events 3(1), 63-86. 
[19] Jupir, M. M. 2013. Implementasi kebijakan pariwisata berbasis kearifan lokal (studi di Kabupaten Manggarai Barat). Journal of Indonesian Tourism and Development Studies 1(1), 28-37.

[20] Indraswara, M. 2008. Evaluasi penerapan rencana tata ruang resort pariwisata Gil Trawangan-Nusa Tenggara. Jurnal Ilmiah Perancangan Kota dan Permukiman 7(1), 1927.

[21] Arieta, S. 2010. Community based tourism pada masyarakat pesisir; dampaknya terhadap lingkungan dan pemberdayaan ekonomi. Jurnal Dinamika Maritim 2(1), 71 79.

[22] Dritasto, A., and A. Anggraeni. 2013. Analisis dampak ekonomi wisata bahari terhadap pendapatan masyarakat di Pulau Tidung. Jurnal Online Institut Teknologi Nasional 20(10), 1-8.

[23] Haryanto, J. 2013. Implementasi nilai-nilai budaya, sosial, dan lingkungan pengembangan desa wisata di Provinsi Yogyakarta. KAWISTARA 3(1), 1-116.

[24] Ramkissoon, H., L. D. G. Smith and B. Weiler. 2013. Relationships between place attachment, place satisfaction and proenvironmental behaviour in an Australian National Park. Journal of Sustainable Tourism 21(3), 434-457.

[25] Rosita, M. Karim and N. Haq. 2016. Strategi pemerintah dalam peningkatan Destinasi Manajemen Organisasi (DMO) pariwisata di Kabupaten Tana Toraja. Jurnal Administrasi Publik 2(2), 207-219.

[26] Nickson, D. 2007. Human management for the hospitality and tourism industries. Elsevier Ltd. Burlington.

[27] Erskine, L. M. and D. Meyer. 2012. Influenced and influential: the role of tour operators and development organisations in tourism and poverty reduction in Ecuador. Journal of Sustainable Tourism 20(3), 339357.

[28] Hays, S., S. J. Page and D. Buhalis. 2013. Social media as a destination marketing tool: its use by national tourism organisations. Current Issues in Tourism 16(3), 211-239.

[29] Lundberg, C. and P. Fredman. 2012. Success factors and constraints among nature-based tourism entrepreneurs. Current Issues in Tourism 15(7), 649-671.

[30] Singgalen, Y., P. Wiloso, and G. Sasongko. 2017. Evaluation of implementation of tourism policy. Jurnal Kebijakan dan Administrasi Publik 21(1), 82-106.

[31] Jordan, E. J., C. A. Vogt, L. E. Kruger and N. Grewe. 2013. The interplay of governance, power and citizen participation in community tourism planning. Journal of Policy Research in Tourism, Leisure and Events 5(3), 270-288.

[32] Ruhanen, L. 2013. Local government: facilitator or inhibitor of sustainable tourism development? Journal of Sustainable Tourism 21(1), 80-98.

[33] Albrecht, J. N. 2013. Networking for sustainable tourism - towards a research agenda. Journal of Sustainable Tourism 21(5), 639-657.

[34] Jovicic, D. Z. 2014. Key issues in the implementation of sustainable tourism. Current Issues in Tourism 17(4), 297-302.

[35] Sakata, H. and B. Prideaux. 2013. An alternative approach to community-based ecotourism: a bottom-up locally initiated non-monetised project in Papua New Guinea. Journal of Sustainable Tourism 21(6), 880-899.

[36] Wesley, A., and C. Pforr. 2010. The governance of coastal tourism: unravelling the layers of complexity at Smiths Beach, Western Australia. Journal of Sustainable Tourism 18(6), 773-792.

[37] Hyman, T. A. 2014. Assessing the vulnerability of beach tourism and nonbeach tourism to climate change: a case study from Jamaica. Journal of Sustainable Tourism 22(8), 1197-1215.

[38] Lee, C. F., H. I. Huang and H. R. Yeh. 2010. Developing an evaluation model for destination attractiveness: sustainable forest recreation tourism in Taiwan. Journal of Sustainable Tourism 18(6), 811-828.

[39] Komarsa Gandasasmita, M. J. W. N. 2015. Arahan pembangunan obyek wisata menuju pembangunan pariwisata berkelanjutan di Kabupaten Wonogiri. Jurnal Kawistara 5(3), 221-238.

[40] Iorio, M. and A. Corsale. 2014. Communitybased tourism and networking: Viscri, Romania. Journal of Sustainable Tourism 22(2), 234-255.

[41] Dredge, D. 2007. Community development through tourism. Annals of Tourism Research 34(4), 1097-1099.

[42] Smith, V. L. and X. Font. 2014. Volunteer tourism, greenwashing and understanding responsible marketing using market 
signalling theory. Journal of Sustainable Tourism 22(6), 942-963.

[43] Su, M. M. and G. Wall. 2012. Global-local relationships and governance issues at The Great Wall world heritage site, China. Journal of Sustainable Tourism 20(8), 10671086.

[44] Condel, R., I. N. Alecu, A. Popescu and H. N. Ciocan. 2016. The analysis of the human resources involved in the rural tourism in Romania. Scientific Papers Series Management, Economic Engineering in Agriculture and Rural Development 16(2), 85-93.

[45] Novelli, M. 2008. In: Burns, P. (Ed). Tourism development-growth, myths and inequalities. Biddles Ltd, King's Lynn. London UK.

[46] Raharjana, D. 2012. Membangun pariwisata bersama rakyat: kajian partisipasi lokal dalam membangun desa wisata di Dieng Plateau. KAWISTARA 2(3), 225-328.

[47] Rahayu, S., U. Dewi and K. Fitriana. 2016. Strategi pengembangan community based tourism sebagai upaya pemberdayaan ekonomi masyarakat di Kulon Progo. Jurnal Kajian Ilmu Administrasi Negara NATAPRAJA 4(1), 65-80.

[48] Singgalen, Y. 2016. Persepsi, modal sosial, dan kekuasaan aktor dalam perumusan dan implementasi kebijakan pariwisata. Jurnal Pax Humana 3(2), 83-105.

[49] Su, M. M., and G. Wall. 2015. Community involvement at Great Wall world heritage sites, Beijing, China. Current Issues in Tourism 18(2), 137-157.

[50] Hilman, Y. 2018. Regional development of tourism in Ponorogo Regency, East Java. Journal of Indonesian Tourism and Development Studies 4(3), 91-96. 